ISSN 1676-3742

\title{
Jesus como sentido último da história humana. Elementos da Cristologia de W. Pannenberg
}

Romildo Henriques Pinas

\section{Resumo}

O presente artigo aborda a Cristologia de Pannenberg, evidenciando o valor histórico e antropológico dessa temática para a afirmação da universalidade da salvação cristã. Em um primeiro momento, depois da introdução, o estudo debate sobre o tema da encarnação do Filho, para logo mostrar Jesus como o protótipo de pessoa humana. Na encarnação como um fato histórico, converge a história de toda humanidade. $\mathrm{O}$ artigo pontua ainda o tema do Reino de Deus enquanto perspectiva da realização da vida humana, o tema da liberdade cristã e a ressurreição de Jesus como porta para a realização plena do ser humano.

Palavras-Chave: Antropologia, Esperança, História, Jesus Cristo, Pannenberg.

\begin{abstract}
The aim of this paper is a reading into Pannenberg's Christology, highlighting the historical and anthropological value of this for the affirmation of the universality of salvation in Christianity. In a first moment, after the introduction, the paper discusses about the topic of the incarnation of Son, then to show Jesus as the prototype of the human person. In the incarnation, as
\end{abstract}


a historical fact, converges the history of mankind. The article also points out the Kingdom of God as a perspective of realization of human life, the theme of Christian liberty and the resurrection of Jesus as the door to the fullness of being human.

Keywords: Anthropology, History, Hope, Jesus Christ, Pannenberg.

\section{Introdução}

O presente artigo busca expor alguns elementos da cristologia de W. Pannenberg que fundamentam o sentido último para a história humana. O trabalho procura pela via histórica apresentar a fundamentação desse autor para o sentido último da vida humana. A cristologia de Pannenberg não deixa de ser relevante devido ao seu viés antropológico-histórico, porém não deixando também de ser polêmica. $O$ texto que será aqui apresentado não estará preocupado em debater tais conflitos, mas apresentar alguns elementos da cristologia desse teólogo luterano, que muito nos podem ajudar na vivência da fé cristã e na nossa infindável busca da resposta à pergunta Quem é Jesus?

Já de início podemos dizer que a fundamentação do valor universal da salvação cristã não deixa de ser um fato intrigante. Pergunta-se: como um acontecimento particular, situado em um determinado espaço e tempo, pode atingir a totalidade da história? A resposta para a problemática só é possível quando o ser humano tem presente o dado da fé. Para aceitar a universalidade da salvação, é necessário crer que o acontecimento da história humana esteja vinculado ao Deus criador. Para tal compreensão, não se pode perder de vista que a história é o lugar por excelência onde Deus vai se revelando. No seu ato revelador, Ele chega à plenitude com a encarnação histórica do Logos na pessoa de Jesus. Em Jesus Cristo surge uma nova imagem do ser humano.

Além do tema da encarnação que será tratado nesse artigo, há outros elementos da cristologia de Pannenberg que são fundamentais para responder à pergunta do valor universal do evento Jesus Cristo. O nosso estudo terá a preocupação com a fundamentação histórico-cristológica para o sentido último que envolve o ser humano. A temática antropológica, de certo modo, aparece na nossa abordagem, sobretudo quando falamos da encarnação do Filho de Deus. Deus se faz homem e vem morar entre nós. A encarnação histórica de Jesus representa a salvação para toda humanidade. Esse princípio se torna indispensável para a fé cristã e se concretizou na entrada do Filho no mundo e 
na sua obediência filial ao Pai. Jesus se encontra numa relação contrária com o ato de Adão, uma vez que não sucumbiu à tentação de ser igual a Deus, como foi o caso do primeiro homem, mas se fez obediente até a morte ${ }^{1}$.

O tema do Reino também se faz relevante, mas o trataremos numa perspectiva de universalidade cristológica. Pannenberg evidencia que a espera escatológica do Messias, como portador do Reino de Deus, faz-se realidade em Jesus, e isso tem conseqüência universal. Entretanto o ponto mais essencial para conferir a universalidade da história de Jesus é o fato da sua ressurreição realizada pelo Pai. Esse acontecimento faz com que, de forma proléptica, toda pessoa já tenha experimentado em Jesus tal realidade. Nele, cada pessoa já participa da ressurreição dos mortos. O que já foi realizado em Jesus se revela realidade em cada pessoa. A espera de um salvador, desde o antigo Israel, torna-se acontecimento em Jesus Cristo. "O que em Jesus uma vez já aconteceu, irradiou para todos e em comunhão com ele na fé, tal realidade já nos aguarda" ${ }^{2}$. Na pessoa de Jesus a humanidade vive a sua liberdade plena. Todos os pontos indicados acima deverão levar em consideração o tema da história, uma vez que para nosso teólogo, somente na história é possível compreender a pessoa de Jesus Cristo.

\section{O Verbo se encarna e o ser humano se reconcilia com Deus na pessoa de Jesus Cristo}

A afirmação joanina "o Verbo é a verdadeira luz que ilumina todos os homens" (Jo 1,9) sinaliza para a encarnação do Filho como um fato que muda a história da humanidade. Jesus participa da comunidade humana e a sua missão é reconciliar a humanidade com Deus, libertando-a de todas as amarras e pecados. Em Jesus, o ser humano é portador da Graça e do amor de Deus. O Verbo de Deus se faz pessoa para elevar o ser humano à Graça de Deus, reconciliando-o definitivamente com seu criador.

Conforme a tradição judaico-cristã, o ser humano é criado à imagem e semelhança de Deus, mas, devido à queda no pecado da desobediência, há um rompimento da relação pessoa-Deus. O Filho se encarna na história humana e assume a missão de reconciliar a humanidade com Deus, na encarnação, bem

\footnotetext{
${ }^{1}$ PANNENBERG, W. Systematische Theologie. Band 2. Gottingen: Vandenhoeck \& Ruprecht, 1991, p. 335.

2 PANNENBERG, W. Grundzüge der Christologie. Gütersloh: Gütersloher Verlaghaus Gerd Mohn, 1976, p. 250.
} 
como no cumprimento de sua missão Ele é para os cristãos o novo Adão. Jesus é o mediador definitivo na relação do ser humano com Deus.

No momento em que Jesus assume a história humana, ela ultrapassa os próprios limites e eleva-se à condição de história divina. O ser humano, na sua história, vê-se reconciliado com Deus e espera a plenitude da história como plenitude da própria realização.

Com a encarnação, a esperança de Israel é modificada profundamente e adquire um caráter universal. Agora Jesus é o homem novo e escatológico, a figura definitiva de ser humano, aquele que responde às intenções de Deus, intenções que já se faziam presentes desde a origem do ser humano, na criação. Como já foi afirmado antes, Jesus é o homem novo enquanto se mostra obediente a Deus na sua paixão e morte $(\mathrm{Rm} 5,19)$. Pela ressurreição de entre os mortos, Ele é o modelo definitivo de ser humano transfigurado e plenificado pelo Espírito ${ }^{3}$.

A filiação divina de Jesus, estendida aos cristãos, como está apresentada em Paulo (Rm 8,16; Gl 4,5s), não representa uma novidade absoluta, já que estava presente na fé do povo de Israel. A novidade é que ela vem do dom do Espírito e da comunhão com Jesus Cristo, o Filho de Deus. O Espírito da filiação de Jesus se dá ao ser humano como revelação na encarnação do Filho numa figura humana; a missão de Jesus assume um itinerário histórico. Pannenberg trabalha com a ideia de que é impossível dissociar a pessoa de seu caminho histórico, pois somente na história da pessoa é que se desenvolve a identidade como personalidade, é a totalidade da existência que definirá os indivíduos dos quais se reconta a história. ${ }^{4}$

A autodistinção de Jesus do Pai, ao assumir a sua condição de criatura, afirma o fundamento da própria possibilidade e realidade de cada existência criada. A pessoa pode, por Jesus Cristo, superar através da própria autonomia as dificuldades e limites, realizando a sua vocação, elevando-se além das

\footnotetext{
${ }^{3}$ PANNENBERG, W. Op. Cit. p. 356. Ao refletir a problemática cristológica, percebemos que o teólogo em questão propõe uma superação para as dificuldades, apontando não a encarnação como ponto de partida para explicar o humano e o divino em Jesus, mas a história concreta. Tempo e eternidade não são vistos de forma dualista, numa relação de exclusão, mas como inclusão. A encarnação de Deus em Jesus Cristo aparece como uma intenção que havia em Deus desde a eternidade. Contudo só se chega a tal verdade pelo acontecimento temporal de caráter definitivo. ${ }^{4}$ Cf. Ibid., p. 360. Para Pannenberg a fundamentação da unidade de Jesus com Deus está na força retrospectiva de sua ressurreição. Faz-se compreensível, então, o caráter oculto evidenciado durante a vida terrena de Jesus e dá-se, portanto, espaço à genuína humanidade de sua existência.
} 
fragilidades presentes na vida que constituem uma situação de escravidão e alcançar a verdadeira libertação ${ }^{5}$.

O Filho, ao assumir a condição humana com a encarnação, se torna uma referência absoluta de perfeição para todos os seres humanos. Pannenberg cita o quarto evangelho para lembrar que: Deus enviou seu Filho ao mundo para salvá-lo (Jo 3,17; 6,38s). Desse modo, a missão de Jesus tem seu fim: a humanidade, libertá-la do pecado e da morte e reconciliá-la com Deus ${ }^{6}$. As expectativas sobre Jesus junto do seu povo não foram realizadas conforme o esperado, pois Ele não foi o libertador político desejado por eles. A libertação que ele propõe propicia ao ser humano a verdadeira comunhão com Deus. Jesus, no seu confronto com a lei judaica, mostra que ela deve se libertar do partidarismo, abrindo-se a todos os seres humanos. Pela sua morte e ressurreição, Ele deixa de ser o Messias só dos hebreus, tornando-se de toda humanidade. A sua missão é unir os seres humanos a Deus, segundo a imagem do ser humano novo e escatológico ${ }^{7}$.

Por fim, Jesus já revela no presente o que a humanidade será no futuro. Ele, ressuscitado dos mortos, representa o futuro escatológico do ser humano, revelando-se como o "já" teológico, como a esperança realizada para o ser humano que "ainda não" experimenta em plenitude a própria salvação. Jesus já é o protótipo da realização humana, antecedendo-nos como mediador e reconciliando-nos com Deus. É nesse sentido que se pode afirmar que a nossa salvação se fundamenta n'Ele. Jesus nos liberta e nos dá novamente a qualidade de filhos de Deus. A ação de Deus na história, pela encarnação, abre à humanidade um horizonte de esperança e de futuro. É uma esperança futura que marca o caminho da pessoa como fim definitivo, e, tal fim acontece no tempo escatológico, momento de plena realização do ser humano em Deus.

\footnotetext{
${ }^{5}$ Cf. Ibid., p. 361.

${ }^{6}$ Pela teologia paulina, Pannenberg traz à tona o tema da filiação divina de Jesus, associando-o com a confirmação de fé na sua messianidade. Os enunciados da primeira experiência cristã caracterizam a figura do homem escatológico não somente ao restrito mundo da fé hebraica, mas adquire um alcance universalizante.

${ }^{7}$ PANNENBERG, W. Systematische Theologie. Band 2, 1991, p. 363 et. seq. Faz-se importante lembrar que o teólogo alemão atribui em sua obra um respeitável lugar à escatologia. É no eschaton que será revelado à pessoa a plenitude de seu ser.
} 


\section{A compreensão teológica da pessoa de Jesus enquanto encarnação na história}

Pannenberg expõe a impossibilidade de se falar qualquer coisa sobre Deus caso não se leve em consideração o processo revelatório como um suceder de acontecimentos na história. $\mathrm{O}$ mesmo argumento vale para a história de Jesus Cristo. A cristologia de nosso autor é elaborada a partir dos dados cristológicos manifestados na história. É partindo desse princípio, que se pode justificar o seu longo itinerário no tema da revelação como história. Para ele a pessoa humana depara com o mistério de Deus e da salvação nos fatos históricos, revelados por Ele ${ }^{8}$. Mesmo que Deus tenha sempre no decorrer da vida humana se dado a conhecer, a plenitude do seu revelar somente acontece em Jesus Cristo. A vida e a história de Jesus de Nazaré é o fato singular, único e de valor universal. ${ }^{9}$

O teólogo da história desenvolve a problemática, mostrando que na igreja antiga toda história da cristologia, em grandes linhas, apresentava a encarnação como o movimento de Deus até o ser humano. Somente depois, essa ideia foi reformulada com o pensamento de Irineu. O bispo de Lyon demonstrou na encarnação a realização do destino da perfeição humana. Jesus é, de

\footnotetext{
${ }^{8} \mathrm{O}$ conceito de mediação parece importante para compreender a cristologia aqui exposta. Ao mostrar a auto-revelação indireta de Deus, o autor em questão traz para o cenário teológico essa temática. Não há dúvida que a base de sua argumentação é toda literatura intertestamentária. Não faltam na sua formulação teológica, textos que indicam o uso de pessoas como mediadoras no Primeiro e no Segundo Testamento. Ele exprime que o mais legitimo mediador é Jesus Cristo. Pelo que percebemos o tema dos sacramentos, como mediação, não caracteriza um dado de grande relevância na sua teologia.

9 PANNENBERG, W. Anthropologie in theologischer Perspektive. Göttingen: Vandenhoeck \& Ruprecht, 1983. p. 482 et. seq. Com a encarnação do Filho a história salvífica não cria um conceito de ser humano, mas o recoloca, dando a ele um novo sentido. Em Jesus Cristo, a história humana e a história divina se encontram. O ser humano pecador, representado na queda de Adão é o mesmo que experimenta a plenitude da vida na história da vinda de Jesus Cristo. Deus vai instruindo o ser humano de forma processual. Assim, é Deus quem vai agindo na construção da história humana mesmo que em momento algum ele desconsidere a autonomia e a liberdade do indivíduo. Deus, didaticamente contribui para que a história humana, enquanto história da salvação (em que Deus vai se revelando) há de ser um processo em que o ser humano se forme até ascender à humanidade plena. Isso só é possível, diz Pannenberg, pelo governo da providência divina. Ele lembra "não tem que entender a providência de Deus como o estabelecimento fixo e prévio ao curso histórico dos acontecimentos e, por outra parte, tão pouco exclui que o ser humano e sua ação participem no processo de formação que é a história". Conferir na mesma obra citada nessa nota as p. 500-501.
} 
forma proléptica, o que acontecerá com todo ser humano ${ }^{\mathbf{1 0}}$. Pannenberg expõe que não é fácil falar da encarnação da segunda pessoa da Trindade como algo isolado, pois a vida de Jesus se encontra situada dentro do todo do acontecer da história da salvação. O método teológico usado por ele mostra que a encarnação acontece dentro do processar da historicidade humana. Ela caracteriza apenas um momento no todo da história e da vida de Jesus Cristo. Com isso, não se pode negar que, se o Filho não tivesse se encarnado (fato histórico), seria impossível para a teologia formular uma compreensão sobre ele e sobre sua história. Também seria ininteligível falar de redenção como participação no Logos divino, o que já havia intuído Atanásio em sua teologia ${ }^{11}$.

A reflexão de Pannenberg sobre a encarnação perfaz o caminho da igreja primitiva e da patrística. Ele deixa claro que o envio do Filho não está desvinculado de sua preexistência, de seu ser na eternidade de Deus em correspondência com a eternidade do Pai ${ }^{12}$. Conforme a tradição bíblica, a encarnação do Filho já fora prenunciada pela compreensão da noção de filho na história de Israel. Isso pode ser observado na designação do rei judaico como filho de Deus, na promessa de Natã a David (2Sm 7,14; S1 89,27s). Quando se estabelece tal relação, compreende-se que a salvação não sofre uma ruptura com o nascimento de Jesus, ao contrário, ela chega ao seu auge, à sua plenitude. É relevante a afirmação de Paulo, apresentando Jesus como segundo Adão, pois isso remete obrigatoriamente à origem da história humana, indicando uma continuidade na história salvífica. O texto de $(\mathrm{Gl} 4,4)$ expressa o envio e o nascimento humano de Jesus, afirmando que Ele não rompe com a tradição mosaica, mas se submete a ela. Jesus participa como ser integral de todas as condições e circunstâncias da vida (diz o apostolo dos gentios: exceto no pecado). A mesma compreensão, já presente nos primórdios do cristianismo, constitui o fundamento da filiação divina de Jesus e de sua união com

\footnotetext{
${ }^{10}$ PANNENBERG, W. Grundzüge der Christologie, 1976, p. 33.

${ }^{11}$ Cf. Ibid., p. 33. Atanásio compreendia a encarnação como o cumprimento do destino humano de participar do Logos na pessoa de Jesus Cristo. Para Gregório de Nissa, a totalidade do ser humano somente pode ser salva quando Deus assume essa totalidade em si mesmo como aconteceu com a encarnação.

12 PANNENBERG, W. Systematische Theologie. Band 2, p. 357. Ainda no assunto mencionado acima, cabe lembrar que as longas contendas teológicas, no decorrer de séculos, foram devido ao desajuste na forma de compreender a pessoa de Jesus. Uns deram muito acento ao seu lado divino, outros preferiam a sua dimensão especificamente humana. Calcedônia, na verdade tentou equilibrar as diferenças existentes entre Alexandria e Antioquia, mas como fala Pannenberg, isso não foi possível. Na verdade o problema cristológico continua a perdurar, ou seja, a resposta de Calcedônia, mesmo como dogma de fé não se faz satisfatória para nosso autor.
} 
o Pai. A afirmação anterior já exprime a ideia de que a natureza de Jesus não é puramente humana. Questão que posteriormente foi definida pelo concílio de Calcedônia e que se faz vigente na dogmática cristã até os dias atuais: em Jesus estão presentes duas naturezas: a humana e a divina ${ }^{13}$.

O ponto de partida para uma avaliação teológica da singularidade histórico-humana de Jesus de Nazaré, como meio da revelação do Logos divino, tal como pode ser reconhecida, deveria ter sido desenvolvido a partir da tipologia adâmica de Paulo; a mesma foi bloqueada na história da cristologia da Igreja antiga, quando essa identificou a encarnação do Logos com o nascimento de Jesus ${ }^{14}$.

“A cristologia da Igreja antiga não conseguiu descrever adequadamente sua relação com a peculiaridade histórico-humana da atuação pública de Jesus, tal como resulta das tradições evangélicas. Ela coloca todo caminho de Jesus, de antemão, sob o sinal da encarnação do Logos divino em seu nascimento, desse modo, a interpretação da tipologia adâmica de Paulo não conseguiu fazer jus ao fato de que o aparecimento do novo Adão, Jesus Cristo, (1Cor 15,45ss), foi associado com a nova vida do Ressuscitado em ( Rm 5,13s), com a obediência filial de Jesus Cristo em seu caminho para a cruz, mas em nenhuma das duas passagens seu aparecimento foi associado a seu nascimento" ${ }^{\prime 15}$.

Outro aspecto considerado é que a cristologia da Idade Média e do protestantismo antigo não tiveram como formular de modo franco a pergunta sobre a singularidade humana de Jesus em sua atuação e em seu destino, pois elas, do mesmo modo, viram como óbvia a geração e o nascimento de Jesus Cristo com a encarnação do Logos. O que fica evidente é que a interpretação

${ }^{13}$ PANNENBERG, W. Grundzüge der Christologie, 1976, p. 300. Na página aqui citada o autor afirma: "Das Dilema dieser beiden christologischen Lösungsvege ist unüberwindlich, solange man die Christologie vom Inkarnationsgedanken her entwickelt, statt sie umgekehrt in der Inkarnationsaussage als ihrem abschliessenden Satz gipfeln zu lassen. Der falsche Ansatz ist aber beiden Konzeptionen gemeisam, ob man nun mit den Antiochenern sagt, der Logos habe bei der Inkarnation einen vollständigen Menschen angenommen, oder ob es mit den Alexandrinern heisst, der Logos habe nur die menschiliche Natur angenommen"

${ }^{14}$ PANNENBERG, W. Systematische Theologie. Band 2, p. 341. Pannenberg frisa que essa identificação não é compatível com o que é afirmado em (Jo 1,14). A afirmação da encarnação, neste versículo, não se refere especificamente ao nascimento de Jesus, como também não em (1 Jo, 4,2). A referência é ao todo de sua existência e atuação terrena que reflete a "graça e fidelidade" de Deus como Pai. Também em (Jo 3,16), quando se fala do envio do Filho ao mundo, está dizendo da paixão e morte de Jesus. O mesmo é o que acontece em (1Jo 4,9).

${ }^{15}$ Ibid., p. 343. 
das Escrituras feita pela escola de Antioquia $^{16}$ foi a que talvez mais tenha procurado abrir espaço à humanidade histórica de Jesus.

Por último, cabe dizer que Pannenberg empenha-se para achar uma solução para a problemática cristológica aqui abordada. Ele se esforça pelo caminho da história em formular uma cristologia que integre a vida de Jesus numa perfeita unidade histórica. O seu empenho pela via histórica e da antropologia acrescenta contribuições para melhor entender a pessoa de Jesus. Harmonizar a encarnação com a ressurreição, ou seja, o pré-pascal e o pós-pascal, continua sendo uma busca incessante da Igreja cristã. É na busca de tal compreensão que se dará possibilidade ao cristianismo de apresentar Jesus como o salvador de toda humanidade. Pannenberg se empenha para fundamentar a validade de seu argumento cristológico na missão de Jesus, na sua obediência ao Pai e na ressurreição. É considerando as características mencionadas que ele consegue adentrar um pouco mais na vida e na história de Jesus de Nazaré, mostrando que nela se realiza a plenitude da vida de todo ser humano. Pela história de Jesus se pode compreender o projeto revelador do Pai e a oferta da salvação para todos.

\section{Jesus Cristo como protótipo de pessoa na antropologia teológica cristã}

O ser humano, por natureza, é portador da dimensão religiosa. O religioso constitui elemento essencial da pessoa na sua realidade como ser. Tal dimensão eleva a pessoa até o seu destino mais autêntico e original, o de ser imagem e semelhança de Deus. O aprofundamento antropológico que o ser humano faz na busca intensa de si como totalidade, faz com que ele não seja um ser fechado em si mesmo, mas ao contrário, que se abra numa atitude de amor e gratuidade ao mundo, ao outro e a Deus - cumprindo, assim, seu destino mais essencial.

Nessa parte do artigo, faz-se necessário mostrar que para o teólogo luterano o modelo perfeito de ser humano é Jesus Cristo; Jesus é também aquele que representa a superação dos limites e das fragilidades humanas. É n'Ele que o ser humano se eleva ao seu destino final e alcança a sua plenitude, destino já presente na criação pelo traço divino deixado na pessoa pela imago Dei.

\footnotetext{
${ }^{16}$ Essa escola procurou valorizar a liberdade e a dimensão humana de Jesus. Para ela o Logos assumiu a condição humana em todos os seus limites. O percurso salvífico vai sendo construído a partir da liberdade histórica de Jesus. Por isso, Antioquia valoriza a humanidade de Jesus, mas não perde a ideia de unidade de pessoa.
} 
Pannenberg apresenta Jesus Cristo como modelo para o ser humano, afirmando assim a sua posição antropológica: a salvação da pessoa está em Jesus Cristo. Não se trata de uma salvação fora da história e alienada do mundo, ao contrário, ela se dá na história do ser humano situado no mundo. Também não se pode esquecer de afirmar que o Filho se faz ser humano, encarna-se para elevar toda humanidade à condição divina. A antropologia adquire um caráter cristológico e a cristologia se fundamenta no ser humano revelado em Cristo Jesus.

Nos longos estudos e debates cristológicos ${ }^{17}$, sempre esteve presente a essa temática qual o caminho a ser seguido na cristologia. Ao definir o caminho, definia-se também o tipo de abordagem cristológica, bem como as implicações na antropologia cristã. Pannenberg traz uma reflexão que apresenta Jesus Cristo como Filho de Deus, relacionando a filiação com a sua missão no mundo (Gl 4,4; Rm 8,3). Assim, a fé cristológica nasce da proclamação de que Jesus é o Cristo de Deus. Desse modo, é no homem Jesus que se autorevela o Filho preexistente de Deus. Ele é revelado pela mediação humana no concreto da história. Ao afirmar Jesus Cristo como modelo de pessoa, Pannenberg pontua a dimensão escatológica dessa afirmação e o homem novo vem contrapor ao Adão, primeiro homem. Mais que tal contraposição, os cristãos começaram a ver no homem novo o ser humano escatológico, revelado em Jesus Cristo como destino de perfeição do ser humano, como pensava o apóstolo Paulo ${ }^{18}$.

$\mathrm{Na}$ encarnação do Filho, cumpre-se a ordem de salvação (economia) prevista para o ser humano desde a origem e que encontra seu aperfeiçoamento em Jesus Cristo. Se a pessoa, como ser finito, não conseguiu a perfeição do início ao fim, sendo incapaz de entrar imediatamente na perfeita comunhão com Deus, então Deus enviou o Logos para que libertasse o ser humano do domínio da morte e de suas debilidades, permitindo-lhe conseguir tal perfeição e conduzindo-o à perfeita comunhão com Deus ${ }^{19}$. Em

\footnotetext{
${ }^{17}$ Nesse momento não cabe entrar nos debates cristológicos acontecidos no decorrer da história, pois isso fugiria da finalidade específica deste artigo. Vale apenas mencionar o longo caminho bíblico-dogmático realizado com o intuito de chegar a uma síntese na compreensão de Jesus Cristo. Polarizando toda a dialética cristológica, quase sempre se fizeram presentes os que defendiam uma cristologia descendente e outros que optavam por uma cristologia ascendente, havendo ainda aqueles que buscaram uma articulação mais harmoniosa entre as duas cristologias. Pannenberg não menospreza nenhuma das duas, mas fica evidente na sua posição uma opção de fundamento histórico e, portanto, com traços mais característicos de uma cristologia ascendente, mas há quem diga que ele integra a cristologia de baixo com a do alto. Cf. O’ DONNELL, John. Pannenberg's doctrine of God. Gregorianum, Roma, v. 72, nº. 1, 1991, p. 553. ${ }^{18}$ PANNENBERG, W. Systematische Theologie. Band 2 , p. 336.

${ }^{19}$ Cf. Ibid., p. 373.
} 
Jesus Cristo, o ser humano é transformado na verdadeira e plena imagem do homem novo, o celeste.

O teólogo alemão traz à evidência, em conformidade com o apóstolo Paulo, a ideia de uma humanidade que se renova na obediência, morte e ressurreição de Jesus. A cristologia paulina apresenta Jesus como novo Adão, isso influirá de maneira profunda também na teologia patrística. Para Paulo, os seres humanos igualmente marcados pelo pecado e pela morte superam tais realidades pelo batismo e pela fé ${ }^{20}$. Conforme os textos paulinos, se pela culpa de um só homem todos foram condenados ao pecado, agora no novo homem, por uma única pessoa, todos foram libertados do pecado e da morte.

A presença do homem novo, como portador da salvação para o ser humano decaído, é revelada na pessoa de Jesus Cristo que entra na natureza humana para libertá-la de suas fraquezas. Ele aparece como salvador. Nesse sentido, a teologia do Novo Testamento revela Jesus obediente até a morte para a salvação de todos ${ }^{21}$.

A cristologia antiga, embora tentasse individuar a divindade de Jesus na sua característica específica de homem celeste, conheceu e evidenciou também uma outra singularidade que conota a natureza humana de Jesus enquanto tal, no seu diferenciar-se do Logos e de todos os outros seres humanos, devido a sua impecabilidade. Na mesma direção foi a afirmação cristológica do concílio de Calcedônia ${ }^{22}$ : O Filho de Deus, encarnando-se, é em tudo igual a nós, menos no pecado. A Igreja antiga buscou esse fundamento na perfeição moral de Jesus e na firmeza de sua união com Deus. A única qualidade que caracteriza o ser humano de Jesus na sua especificidade derivaria assim, de seu ser-por-si individual, ideia que influirá em certas interpretações modernas da santidade de Jesus ${ }^{23}$.

\footnotetext{
${ }^{20}$ Cf. Ibid., p. 345.

${ }^{21}$ Cf. Ibid., p. 345.

${ }^{22} \mathrm{O}$ Concílio de Calcedônia afirmou a perfeita humanidade e a perfeita divindade de Jesus, em que se fazem presentes as duas naturezas inconfusas e imutáveis; indivisas e inseparáveis. Calcedônia foi uma forma de buscar um consenso entre Oriente e Ocidente. Cf. SCHNEIDER, Theodor (org.). Manual de Dogmática, Vol. I. Cristologia. São Paulo: Vozes, 2002, p. 219-400.

${ }^{23} \mathrm{O}$ itinerário da abordagem histórico-dogmática, que buscava definir a divindade e a humanidade de Jesus, não deixou de confirmar as grandes polêmicas e dificuldades que persistiram durante longos séculos. Vários modelos foram formulados até chegar à afirmação de Calcedônia. Vale citar o modelo de Apolinário de Laodicéia (Logos - sarx) como também o Logos - anthropos e suas versões em Antioquia e Alexandria até chegar à conclusão da unidade de Deus Filho e ser humano, Jesus Cristo. A fórmula de Calcedônia hoje constitui fundamento para a cristologia de todas as igrejas cristãs.
} 
Pannenberg, ao elaborar a sua reflexão cristológica na ideia soteriológica do novo Adão, tem presente o princípio da nova humanidade, humanidade da qual Jesus se faz autor pela perfeita unidade com o Pai e pelo sim à sua missão de implantar o reino de Deus no mundo. Jesus se mostra obediente a Deus e solidário com toda humanidade (2Cor 5,21). Por sua morte e ressurreição, ele se transforma em protótipo de uma nova humanidade. Todos os seres humanos deverão se renovar à sua imagem - que é a imagem de Deus (2Cor 3,18), renovação que implica na participação em sua vida. Conforme se lê, a carta aos Hebreus afirma a humanidade de Jesus semelhante aos demais seres humanos em tudo, exceto no pecado ( $\mathrm{Hb} 4,15)$.

A constatação de $(\mathrm{Hb} 4,15)$ tornou-se uma constante na teologia a partir de Irineu de Lyon e Tertuliano. Irineu afirmava o não cometimento de pecado por parte de Jesus, sem com isso afirmar que Jesus tenha tido uma natureza distinta da nossa. Tertuliano também atestava que Jesus assumira a carne pecadora, sem cometer pecado. Ele é um homem sem pecado devido à sua comunhão com Deus. Com tais afirmações, Irineu e Tertuliano vão ao encontro do pensamento paulino, quando Paulo expõe que Cristo se fez um de nós, assumindo a carne de pecado, permanecendo contudo sem pecado, libertando-nos do seu jugo $(\operatorname{Rm} 8,3)^{\mathbf{2 4}}$.

A peculiaridade do Redentor residia na consciência que Ele tinha da presença de Deus em sua pessoa, presença que é motivo da ausência de pecado. Tal consciência é aqui colocada como substitutivo da divindade; Jesus é visto como o Redentor; fundador de uma comunidade de redimidos e os indivíduos, ao serem incorporados a tal comunhão, libertam-se do pecado e participam de uma nova sociedade que é denominada de Reino de Deus ${ }^{25}$. A comunidade do reino de Deus é considerada uma nova etapa da evolução da humanidade. Essa nova realidade, trazida por Cristo, no âmbito da vida humana, é vista como uma nova criação, nova existência humana, mais perfeita, levando a criação humana à sua consumação e à sua plenitude.

Em Jesus, tal consumação acontece no cumprimento livre de sua missão. Diante das tentações que Jesus enfrenta, como se pode ler nos sinóticos, há uma inclinação de confirmar a missão que lhe foi confiada por seu Pai com as expectativas de Israel, esquivando-se da proposta de Deus. O peso da tentação como abandono do caminho disposto por Deus ou o desespero diante dele ficam evidentes em sua oração no Horto das Oliveiras

\footnotetext{
${ }^{24}$ PANNENBERG, W. Systematische Theologie. Band 2, p. 374 et. seq.

${ }^{25}$ Cf. Ibid., p. 276.
} 
(Mc 14,35s; Mt 26,39; Lc 22,40-44) e também na cruz com sua súplica ao $\mathrm{Pai}^{26}$. O contexto da tentação mostra que a fidelidade de Jesus à sua missão pressupõe sua liberdade. Ela acontece no momento em que Ele não recusa uma resposta positiva à sua missão, mantendo-se fiel a tal missão. Pode-se dizer que o drama vivido por Jesus não é solucionado em nenhuma instância humana, é somente no conteúdo de sua mensagem salvífica, assumido na sua missão, missão que provém de Deus e constitui a sua liberdade. É pela autoridade de Deus à qual Jesus recorria em sua mensagem e atuação que seu drama será solucionado ${ }^{27}$. A solução se dá diante da ressurreição e passa a não ser uma experiência pessoal de Jesus, mas acontecimento que atinge a todos os seres humanos. Jesus é o representante de toda a humanidade diante de Deus, e tal fato demonstra que Ele realizou em sua vida a determinação específica do ser humano como tal. Na ressurreição, Ele garante aos demais seres humanos a comunhão com Deus. A cristologia moderna compreende que Jesus é o homem autêntico em sua abertura para Deus, na sua total confiança no futuro, na sua responsabilidade filial em relação ao mundo e à solidariedade com os outros ${ }^{28}$.

Enfim, é mediante a ressurreição que Jesus significa o cumprimento das promessas proféticas escatológicas do povo de Israel, levando a termo os anseios mais profundos de toda a humanidade. $\mathrm{O}$ futuro escatológico representa o revelar do autêntico ser humano dos tempos passados, sendo o ser humano transformado num homem novo, novo Adão. Paulo aos Romanos alerta-nos que "a esperança não engana, pois o amor de Deus foi derramado em nossos corações pelo Espírito Santo que nos foi dado" (Rm 5,5s.). Pelo amor de Deus, manifestado na ressurreição de Jesus Cristo, todos passam a ter acesso à vida nova que surgiu no evento da ressurreição de Jesus. É nesse sentido de vida nova para o ser humano que se entende o tema da reconciliação. Jesus reconcilia a humanidade com o Pai; por ele, Deus renova a sua aliança com a humanidade e novamente a introduz no caminho da salvação. A pessoa humana se vê reconciliada com Deus, portanto é a salvação para toda humanidade, como será apresentado adiante.

\footnotetext{
${ }^{26}$ Cf. Ibid., p.280.

${ }^{27}$ Cf. Ibid., p. 280.

${ }^{28}$ Cf. Ibid., p. 281.
} 
De início é importante levantar algumas perguntas, mesmo que sejam para romper a rotina metodológica adotada nesse estudo. A primeira questão que pode ser significativa é: por que existe a preocupação em buscar convergência entre a vida de um homem que viveu há mais de dois mil anos e a do ser humano que se encontra no século XXI? Teria aquele homem algo a acrescentar à humanidade atual? Em que a história de Jesus supera a de nossos dias? E ainda, em que a vida de Jesus se assemelha e distingue-se da de outros seres humanos? Mesmo que não haja condições de responder a todas essas perguntas, elas funcionam como setas, indicando ao caminhante o norte da reflexão por onde deve seguir.

Já foi abordado o tema que o envio do Filho ao mundo é o culminar da ação reveladora de Deus. Ele vem participar da história do ser humano, e revela o verdadeiro rumo para a pessoa humana. Na sua pessoa a história humana se eleva até Deus. Ela se torna para Deus o campo ou o lugar da revelação de sua sabedoria. Conforme se lê nos textos sagrados, Cristo também pode ser compreendido como a sabedoria que se encarna na história, isso se confirma quando associado aos livros sapienciais do antigo Israel. Está explícito na teologia de Pannenberg que com a encarnação, a história de Deus não se dá à parte, mas ela interage com a da humanidade. A revelação de Cristo não é descontínua com a história humana, mas participa dela e a assume, revelando a essência do ser humano ${ }^{29}$. Na pessoa de Jesus Cristo, todo ser humano precedente foi substituído por uma forma radicalmente nova de ser pessoa.

Jesus, como já dito, é o Adão renovado, não apenas ser vivente, mas espírito vivificante como se lê em $(1 \text { Cor } 15,45 \mathrm{~s})^{30}$. Em vários textos do teólogo luterano, ele identifica em Jesus o modelo para a pessoa humana, mas com isso não se quer dizer que já tenha se realizado em cada pessoa tudo o que já sucedeu n'Ele. Jesus é o protótipo para toda humanidade, e ela deve continuar o seu percurso de vida rumo a sua realização plena que será no fim da história, com a escatologia ${ }^{31}$. Na sua obediência ao Pai, bem como no

${ }^{29}$ PANNENBERG.W. "Fundamentação cristológica de uma antropologia cristã". Concilium 6 (1973), p.733.

${ }^{30}$ Cf. Ibid., p. 734.

${ }^{31} \mathrm{O}$ artigo de José Fernández é suficientemente elucidativo quando mostra o desfecho escatológico mediado pela pessoa do Filho. O Filho encarnado é o testemunho verdadeiro do amor de Deus pela humanidade. Cf. FERNÁNDEZ, José Ramón Matto. “Il Futuro Del Hombre y el ser de Dios. La Escatología Trinitária”. Salmanticensis, Vol. LVI, fasc. 3, p. 445-494, 2009. 
testemunho do reino vivenciado por Jesus, ele se revela como Filho de Deus. Ao chamar Deus de Pai, Jesus está em perfeita sintonia com Ele. Sua filiação implica também a sua forma de se relacionar com Deus, bem como a sua ação. Tal exigência, implícita necessariamente em sua missão, foi o centro da controvérsia que o envolveu, levando-o à condenação e morte na cruz ${ }^{32}$. É evidente que a compreensão de Jesus como salvador da humanidade não é um dado isolado, antes de tudo, ela é um ato de fé; porém é somente mediante o conhecimento $^{33}$ dessa ação salvífica que se torna possível crer nessa verdade. O evento Jesus Cristo não é um fato deslocado na história da salvação, ele faz parte do todo da ação reveladora de Deus.

Pannenberg aborda a problemática da verdade universal da revelação de Deus em Jesus Cristo, deixando claro que Deus usa do meio histórico para se revelar, Ele não vem até o ser humano de forma misteriosa e secreta. Essa é uma proposição que Paulo já havia intuído na sua segunda carta aos Coríntios $(2$ Cor 4,2). É pela Graça do Espírito que o ser humano chega à verdade revelada ${ }^{34}$.

\footnotetext{
${ }^{32}$ PANNENBERG, W. “Jesus Cristo - o critério da nossa fé no verdadeiro e único Deus". Humanística e Teologia, Vol. 3, ano 2003, p.337-356.

${ }^{33}$ Opta-se pelo termo conhecimento, mesmo que o mais adequado pareça ser experiência. $\mathrm{O}$ termo experiência, um pouco adverso ao autor em questão, suscita sempre algumas ambigüidades quando por ele usado. Talvez poucas vezes ele o mencione no sentido de uma experiência como sentimento espiritual. O conceito de experiência, mesmo que não haja aqui toda clareza sobre a questão, mostra estar muito mais ligado às ciências naturais - empirismo: uma experiência capaz de medir resultados objetivos. Não é por menos, uma das criticas atribuídas a Pannenberg: racionalista. Sobre a atribuição a Pannenberg de racionalista conferir a aguda crítica de Clodovis Boff feita na REB. Cf. BOFF, Clodovis. Recensão da obra Teologia sistematica 1, Queriniana: Brescia, 1990. REB, Petropolis, v. 52, n. 205, p. 229-230, mar. 1992. Também LeRon Shults mostra a presença desse aspecto na teologia de Pannenberg. A sua obra: The Postfoundationalist Task of Theology: Wolfhart Pannenberg and the New Theological. Grand Rapids: Eerdmans, 1999, traz uma racionalidade como tarefa pós-fundamentalista. E para uma crítica à obra de Shuts consultar a recensão: VILADESAU, Richard. Recensão da obra The Postfoundationalist Task of Theology: Wolfhart Pannenberg and the New Theological. by F. LeRon Shults. Grand Rapids: Eerdmans, 1999. Theological Studies, Washington, v. 61, n. 3, p. 594, Sep. 2000.

${ }^{34}$ Anselmo pensou a fé como prioritária, mas quem possui a fé será negligente ao descurar da compreensão daquele em que deposita sua crença. O Arcebispo de Cantuária, demonstrando confiança na razão, admite que o uso da mesma não constitui problema ao que tem segurança em suas convicções, sendo louvável o esforço empenhado para a compreensão racional do objeto de sua crença. Na sua obra Monológio é apresentada uma tentativa de elucidar, pela razão, aquilo que Anselmo acredita pela fé. Ele revela o seu gênio conciliador, ao propor a fórmula: "a fé procura compreender" (Fides quaerens intellectum), porém a fé é graça.
} 
É na abertura aos fatos que se chega à fé, possibilitando a compreensão de que o acontecido na história de Israel até a ressurreição ${ }^{35}$ de Jesus é uma sucessão de feitos muito importantes e particulares. A fé tem a ver com o futuro, pois, do contrário, quem esperaria por algo que nunca iria acontecer? É no sentido de esperança futura que se fundamenta a pregação cristã. Ela anuncia a verdade indubitável da ação reveladora de Deus em Jesus de Nazaré como a salvação de todos os seres humanos ${ }^{36}$.

$\mathrm{Na}$ história de Israel, Yahvé não chegou a se manifestar como Deus uno de todos os homens ${ }^{37}$. Conforme a apocalíptica e o testemunho do Segundo Testamento, no destino de Jesus Cristo já se vê antecipadamente o fim acontecido nele, pois, com sua ressurreição de entre os mortos já aconteceu o que está próximo para todos os seres humanos. Deus, é pertinente dizer, revelou-se de forma definitiva e total no destino de Jesus. N'Ele, Deus chega até o ser humano de forma plena, manifestando definitivamente sua divindade, e o fez como o Deus uno e único de todos os seres humanos ${ }^{38}$. É baseando-se no caráter escatológico da revelação que se torna possível afirmar a definitiva manifestação de Deus, não havendo possibilidade para alguma ulterior. A escatologia permite ver o evento Jesus Cristo como antecipação do fim de todas as coisas. Com isso, não quer dizer que não aconteça nada de novo depois de Jesus Cristo. A história continua acontecendo, mas sob seu sinal. É à luz de Cristo que se pode compreender o processar da história. Depois de Jesus, a história está determinada essencialmente pelo anúncio e pregação da mensagem de Cristo. É pelo caráter escatológico da revelação do Deus de Israel em Jesus Cristo, como universalidade, que se pode falar de pregação do evangelho aos pagãos ${ }^{39}$. Os primeiros cristãos demonstraram uma convicção clara que a revelação do Deus de Israel não era algo diferente da revelação em Jesus Cristo. Os textos paulinos, como também os textos da Igreja primitiva, indicam essa verdade tão evidente no início do Cristianismo. Jesus é a plenitude da promessa feita a Israel e o mediador da nova e eterna aliança (Hb 9.15s).

${ }^{35}$ Cf. PANNENBERG, W. Grundzüge der Christologie . p. 85-112.

${ }^{36}$ Ibid., p. 101.

${ }^{37}$ Ibid., p. 103.

${ }^{38}$ Ibid., p. 104.

${ }^{39}$ Ibid., p. 111. Pannenberg comenta que apesar de algumas diferenças entre compreensão bíblica da revelação de Deus e a compreensão gnóstica, a pregação cristã pode chegar a anunciar a universalidade e definitividade da revelação de Deus no destino de Jesus Cristo mediante as representações gnósticas de revelação. 
A expectativa do cumprimento da promessa de Jesus sobre o reino não permaneceu irrealizada. Essa esperança foi realizada, de uma forma nova, no evento da ressurreição. Em Jesus a expectativa da ressurreição escatológica já se faz realidade para toda humanidade ${ }^{40}$. A pregação da ressurreição pelos primeiros cristãos tem uma importância fundamental para a nova visão de revelação esboçada na teologia de Pannenberg. É na ressurreição de Jesus que se confirma o comportamento pré-pascal do mesmo Deus que o ressuscitou. Por outro lado, o significado que é próprio e imanente à ressurreição está ligado à espera apocalíptica da mesma, pois somente com essa conexão a ressurreição de Jesus é a irrupção do fim esperado por toda humanidade ${ }^{41}$. O evento da ressurreição traz imanente um sentido soteriológico latente, manifestando um novo sentido para a história individual de todo ser humano. Nesse episódio se realiza o verdadeiro significado da descrição que o Gênesis faz do ser humano como imagem e semelhança de Deus (Gn 1 26-27) ${ }^{42}$.

Jesus revelou-se aos seus discípulos como o Cristo de Deus. Na sua vida se cumpriu a esperança messiânica do povo de Israel. A Epístola aos Hebreus apresenta como isso se dá: na obediência ao Pai "Embora fosse Filho, aprendeu a obediência por meio dos sofrimentos que padeceu. E, tendo-se tornado perfeito, fez-se causa de salvação eterna para todos quantos lhe obedecem" ( $\mathrm{Hb} 5,8 \mathrm{~s})$. No sentido da obediência, é também de raro significado (F1 2,5s) que revela o sentido do esvaziamento e da abertura ao projeto do reino ${ }^{43}$. A obediência ao Pai é que capacita Jesus para ter uma relação tão próxima com Ele. Ela é uma característica indispensável para compreender a pessoa e a história de Jesus. Ao ter Jesus como modelo na vivência da fé e da obediência ao Pai, também as demais pessoas, seguindo seu exemplo, podem se colocar na condição de obedientes à vontade de Deus. Dessa forma, a destinação do ser humano de ser a imagem e a semelhança de Deus, que implica também na destinação para a comunhão com Ele, pode ir se realizando. O tornar-se humano de Deus, em Jesus de Nazaré, diz Pannenberg, deverá valer como cumprimento dessa destinação ${ }^{44}$.

\footnotetext{
${ }^{40}$ Ibid., p. 232 et. seq.

${ }^{41}$ Ibid., p. 141 et. seq.

42 Ibid., p. 43.

${ }^{43}$ Jesus é o protótipo de realização humana. Ele revela a capacidade de superar todas as autosuficiências e inconsistências da vida. Isso acontece pela atitude de abertura a Deus e pela obediência ao projeto do Pai.

${ }^{44}$ PANNENBERG, W. Systematische Theologie. Band 2. p. 258s.
} 
O apostolo dos gentios se preocupa em enfatizar a perfeição de Cristo, quando na epístola aos Romanos aponta para o contraste do Cristo com o ser humano do pecado ( $\mathrm{Rm} 5,15)$. A finalidade é exatamente mostrar a peculiaridade de Jesus Cristo como origem de uma nova imagem da pessoa humana. A história de Jesus revela o fim último da história humana. Para Pannenberg é:

"Na unicidade da identidade de Jesus como Filho de Deus: o eterno correspondente do Deus eterno como Pai foi definitivamente realizado nele na forma de um único ser humano. A conseqüência é que o destino de todos os outros homens em atingir a comunhão com o Pai do céu de um modo que corresponda à sua paternidade só pode ser realizado pela participação na relação de Jesus a Deus Pai, participação no seu amor, na sua comunhão de confiança e de obediência com Deus Pai" ${ }^{45}$.

Fora dessa compreensão fica difícil falar de Jesus como sentido último da história humana ou mesmo como salvador da humanidade.

Por fim, somente é possível compreender a vida de Jesus quando considerada em sua totalidade. Entretanto, há alguns traços que adquirem maior relevância quando queremos aproximar-nos de sua história. O tema da obediência filial que, de certo modo já foi tratado acima é um desses traços. Outro aspecto a ser visto é o reino como constitutivo fundamental da história de Jesus. É no reino que se realiza a concretização do amor de Deus ao ser humano como abordaremos no item seguinte.

\section{A pessoa de Jesus e o reino de Deus}

São várias as passagens bíblicas que fazem alusão ao Reino de Deus. A vida de Jesus é apresentada nos evangelhos sempre em função do Reino, uma vez que o Pai exerce seu reinado por meio de Jesus. No decorrer da missão de Jesus, os evangelhos mostram a sua incondicional devoção ao serviço do Reino do $\mathrm{Pai}^{46}$. Ele anuncia um reino que já está imanente e, com isso, Ele não desconsidera o povo da aliança, mas ao mesmo tempo exige a conversão ao seu Deus. Ele prega a proximidade do Reino, não como salvação para o povo

\footnotetext{
${ }^{45}$ PANNENBERG, W. "Jesus Cristo - o critério da nossa fé no verdadeiro e único Deus”. Humanística e Teologia, Vol. 3, ano 2003, p. 344.

${ }^{46}$ PANNENBERG, W. Grundzüge der Christologie . p. 224s.
} 
da aliança, no sentido do antigo pacto estipulado com Deus, mas somente para aqueles que recolocam toda a esperança no futuro de Deus, já iminente. Colocar a esperança no futuro significa responder ao convite lançado por Jesus em sua mensagem ${ }^{47}$. O aceitar a mensagem é, de antemão, aceitar a salvação, compreendendo-a como a realização da destinação humana, realização que consiste no cumprimento da abertura para Deus. O conteúdo do anúncio é uma realidade que já se faz presente para quem ouve e assume a mensagem de Jesus de que o Reino de Deus está próximo ${ }^{48}$.

Jesus fala de um Reino futuro, isso está presente em grande parte das passagens dos evangelhos. Algumas perícopes se referem ao Reino já presente, como em Lc 11,20; 17,20; 10,23 e Mc 2,19. O dilema entre presente e futuro do Reino foi vivido no início da vida cristã. O tempo de espera do reino não significa uma crise na divindade de Deus, e sim, que o ser humano necessita de um tempo como forma de existência e, desse modo, as próprias criaturas vão configurando suas vidas em direção ao futuro de sua destinação que Deus lhes propiciou. Para Pannenberg, o governo mundial de Deus é o modo de seu reinado sobre toda criação, através do qual, ele conduz o curso dos acontecimentos do mundo ${ }^{49}$. O mundo ainda não se encontra preparado para a recepção do Reino na sua plenitude total. Há ainda muitas sombras que o ocultam, essas sombras são coisas horríveis que acontecem na história e assolam a vida humana. Jesus propõe um mundo novo, que revela o despontar do Reino e do futuro escatológico. Ele testemunha, na sua relação com o Pai, que Deus deseja a comunhão com as pessoas. Comunhão que significa a participação na comunhão do Filho com o Pai por meio do Espírito na vida da Trindade, assim o desejo do Pai fica evidente na pregação de Jesus. A comu-

\footnotetext{
${ }^{47}$ PANNENBERG, W. Systematische Theologie. Band 2. p. 367. Além da obra citada aqui nessa nota, o último capítulo da Teologia Sistemática III de Pannenberg é todo dedicado ao tema do Reino. Também muitas páginas de sua cristologia abordam esse assunto, esse tema é o fio condutor de toda mensagem de Jesus Cristo.

${ }^{48}$ PANNENBERG, W. Op. Cit. 1976, p. 334. A pregação de Jesus não é no deserto como o fez João Batista, ele depara com pessoas doentes, desnorteadas, pecadoras e é, sobretudo, para essas que o reino chegou. Ele não coloca nenhuma precondição, basta aceitar a sua mensagem e já perdoa os pecados e a pessoa imediatamente participa do banquete escatológico. Pannenberg não trata com a mesma agudeza da teologia Latino Americana o tema dos sofredores e pobres. A teologia da Libertação, devido ao grave contexto de pobreza, desigualdade e de injustiça social em que vive todo continente, despertou-se para maior desenvolvimento desse aspecto na abordagem cristológica.

${ }^{49}$ PANNENBERG, W. Systematische Theologie. Band 3. Göttingen: Vandenhoeck \& Ruprecht, 1993, p. 626.
} 
nhão com o Deus de Jesus Cristo permitirá ao ser humano viver em verdadeira comunhão com seu próximo. ${ }^{50}$

A mensagem do Reino traz o verdadeiro modelo de justiça. Isso acontece em um contexto judaico marcado por tantas injustiças e pelo domínio da força do pecado na ação humana. A esperança pelo Reino de Deus foi combinada com a concepção de uma transformação das condições naturais da própria existência humana. O Apocalipse fala de novo céu e nova terra (Ap 21,1). É nesse contexto que a esperança pela chegada do Reino de Deus necessariamente está vinculada ao desejo por uma renovação do mundo ${ }^{51}$.

Fica evidente nos evangelhos que a vida pública de Jesus é caracterizada pelo convite feito às pessoas de aceitar incondicionalmente o Reino de Deus anunciado por ele."Buscai primeiro o reino de Deus e sua justiça e todas as outras coisas lhe serão dadas por acréscimo" (Mt 6,33). Pannenberg considera que o dinamismo típico do anúncio que Jesus faz da basiléia está propriamente aqui: o Reino de Deus está eminente e irrompe já no presente; porque o futuro, em substância, é o Deus que na sua unicidade se coloca em modo absoluto à criatura que vive no presente ${ }^{52}$. De certo modo, o Reino já avança no presente das criaturas.

Os sinais do Reino, tão anunciados por Jesus, caracterizam a necessidade de adesão e aceitação para compreender e, ao mesmo tempo, tais sinais apresentam a dimensão escatológica do Reino. A participação no Reino significa também a salvação escatológica da pessoa. A salvação apresentada por Jesus no seu anúncio já se concretiza nos gestos prioritários de sua missão. Para pessoas que viviam sobre ameaças de todos os tipos de sofrimentos, carregando o jugo da imposição religiosa, política ou mesmo com doenças físicas e espirituais, Jesus mostra o amor do Pai. Ele anuncia um Reino de amor. Anuncia um Deus bom que faz surgir o sol sobre os bons e sobre os maus (Mt 5,45). Pela sua pregação e com sua vida, ele revela a chegada do amor redentor que liberta, cura e salva. Pannenberg vê na parábola da ovelha

\footnotetext{
${ }^{50}$ Já no mundo bíblico, os profetas sempre tiveram uma grande preocupação com a vida da sociedade. Jeremias, Ezequiel, sobretudo Isaías aborda incansavelmente esse tema. Os salmos também tratam o tema da justiça e da solidariedade com o próximo. O teólogo luterano não se esquece de acrescentar à abordagem do tema reino de Deus o problema da vida em sociedade. Essa problemática já estava presente na patrística. Muitos procuraram relacionar a perfeição do reino de Deus com os problemas vivenciados no contexto da sociedade humana. A obra de Agostinho se tornou célebre, quando ele desenvolve o tema através da obra A cidade de Deus.

${ }^{51}$ PANNENBERG, W. Op. Cit. 1993, p. 630.

${ }^{52}$ PANNENBERG, W. Systematische Theologie. Band 2. p. 370.
} 
perdida (Lc 18,4-7) como também nas da moeda encontrada (Lc 15,8s) e do pai misericordioso (Lc 15,11-32) sinais concretos da alegria que prova o amor misericordioso de Deus ${ }^{53}$. Nessas parábolas, evidencia-se a afeição de Deus pelas pessoas destituídas de valor junto da sociedade vigente. Esses personagens presentes nos textos vêm participar da salvação escatológica do Reino. Para isso, a precondição é a abertura ao anuncio, a aceitação da mensagem de Jesus. É o perdão dos pecados que elimina a barreira da separação entre pessoa humana e Deus. É correto dizer que a presença do Reino e a participação na sua salvação implicam de antemão a remissão dos pecados e a superação de tudo o que separa a pessoa de Deus.

O Reino não deixa de ter suas exigências e, a maior delas, é a vivência do amor: amar a Deus como já era pedido na tradição de Israel e amar o próximo. O modelo de amor que Jesus apresenta é a sua relação com o Pai, e, também a sua demonstração de amor para com seus discípulos. O amar a Deus sobre todas as coisas já era uma lei na tradição mosaica, a novidade que Jesus apresenta é o amor ao seu próximo, a ponto de amar os seus inimigos (Mt 6,45s). A compreensão de um amor gratuito e sem pré-condições é bem descrita na parábola do bom samaritano (Lc10, 25-37). O texto expõe a relação criativa do amor, podendo ser exatamente ligada ao amor demonstrado por Jesus na forma de acolher e perdoar os pecados e na promessa da salvação ${ }^{54}$. A motivação para a prática do amor muda de sentido, pois agora ela não se baseia na lei e na tradição, mas na bondade do criador e no amor de Deus já manifestado na aproximação do Reino que todo ser humano pode participar. O Reino acontece na revelação da glória de Cristo e na glorificação dos que são interligados por meio da fé em seu retorno. É sustentando-se na afirmação feita acima que há condições de se compreender a transformação do mundo em um novo céu e uma nova terra como se lê em várias passagens bíblicas. $\mathrm{O}$ encontro com o Cristo que retorna, conforme afirma a fé cristã, faz despontar o futuro escatológico. É um futuro que traz à humanidade, através de Jesus ressuscitado e glorificado junto do Pai, pela ação do Espírito, que já atuou desde a encarnação, a salvação definitiva. O "já" do futuro escatológico do Deus eterno pode ser pensado como a sua manutenção do mundo e da criatura que se dá no tempo, pois somente no tempo a criatura pode se relacionar com Deus. $\mathrm{O}$ ato divino de manutenção do mundo confirma a sua forma de amor, pois sem perder em nada na sua eternidade, ele se faz temporalidade junto de sua criatura. Dá-se a entender, assim, algo como a

\footnotetext{
${ }^{53}$ Ibid., p. 372.

${ }^{54}$ PANNENBERG, W. Grundzüge der Christologie. p. 239.
} 
forma de maturação do amor divino. Uma vez que, sem perda na sua eternidade, o amor de Deus produz tempo, atua para dentro do tempo e dessa forma se torna presente nele ${ }^{55}$. Não somente o chamado à existência é fruto do amor criador de Deus, mas também a permissão do ser humano de participar da força vital de seu Espírito e da comunhão trinitária.

O culminar do amor divino acontece com a encarnação, vinda do Filho de Deus até a humanidade. A sua vida e sua história trazem para cada ser humano a mensagem de que Deus o ama e que o quer participante na comunhão trinitária. Claro, isso acontece somente na consumação escatológica quando Deus enxugará todas as lagrimas (Is 25,8; Ap 21,4). Enxugar todas as lágrimas quer dizer que na criação e na história da salvação, a revelação do amor de Deus será elevada acima de qualquer dúvida ${ }^{56}$. Pannenberg conclui o tema do Reino dizendo que em todo percurso da história salvífica, desde o início da criação, passando pela reconciliação, chegando até a consumação escatológica da salvação, tudo isso é expressão do antecipar-se do eterno futuro de Deus para a salvação das criaturas, que não é outra coisa senão a manifestação do amor divino. Diz ele:

"Ele é o alicerce eterno para a separação da imanência da vida divina para a Trindade da economia da salvação e para assim mediada inclusão das criaturas na unidade da vida trinitária. Diferenciação e unidade entre Trindade imanente e econômica formam o batimento cardíaco do amor divino, e com um único desses batimentos ela abraça todo mundo das criaturas" ${ }^{\prime 57}$.

Nosso autor tem consciência que o amor é, em último termo, a única resposta válida para a pergunta sobre o futuro de Deus. O amor é o que abre uma nova existência, unificando todas as coisas criadas. Ele é o motivo decisivo da criação, como antes já foi lembrado. A teologia cristã tomou consciência do valor universal do amor de Deus como foi revelado por Jesus. Pelo amor, Deus concede a graça ao ser humano da participação numa realidade que é maior do que qualquer realidade criada ${ }^{58}$.

Quando se procura compreender o gesto amoroso do Deus criador, torna-se possível de entender também um pouco mais da história pessoal de

\footnotetext{
${ }^{55}$ PANNENBERG, W. Systematische Theologie. Band 3, p. 692.

${ }^{56}$ Cf. Ibid., p. 692.

${ }^{57}$ Ibid., p. 693.

${ }^{58}$ PANNENBERG, W. Teologia e Reino de Deus. Salamanca: Sigueme, 1974, p.31 et.seq.
} 
cada indivíduo. É nesse contexto que se insere a vida e a história de Jesus Cristo. Caso retire da vida de Jesus o que já foi mostrado de sua ação, certamente alteraria a abordagem e o entendimento de sua pessoa. É na relação de obediência ao Pai, na exigência da prática do amor, no anúncio do reino, que já se aproxima e, sobretudo, na sua ressurreição, que se torna possível identificar nele o que deve ser a historia de cada pessoa.

A pergunta quem é Jesus? é uma pergunta dialética, pois ao perguntar quem é Jesus, de certo modo, a pessoa também está formulando a pergunta sobre sua própria existência. Compreendida dessa maneira, a vida de cada indivíduo se encontra com a de Jesus. A abertura de Jesus ao projeto de Deus permite ao ser humano olhar para si mesmo e verificar as suas atitudes de fechamento e de abertura ao projeto de Deus para sua vida.

Finalmente Jesus já é a evidência do que acontecerá com cada ser humano. Se o Reino é uma proposta futura, mas ao mesmo tempo, em Jesus, já se faz realidade, então de algum modo o ser humano já participa dele. É no contexto do reino que a pessoa de Jesus é vista como futuro para toda humanidade. Ele é futuro para o ser humano porque nele já se realizou o reino de Deus. É na sua história que a história humana já vislumbra a plenitude. Ele dá um novo sentido para a historicidade humana uma vez que na sua ressurreição o Pai já revela a cada pessoa a ressurreição definitiva e o seu reinado no mundo.

\section{Jesus como futuro da humanidade - um novo sentido para a historicidade humana}

Já de início cabe recordar que em Jesus Cristo encontra-se o verdadeiro modelo de ser humano. Ele tornou-se possibilidade de realização como pessoa, para todos os outros seres humanos. N'Ele, revela-se a verdadeira essência do ser humano. Pannenberg deixa evidente no seu tratado cristológico que no particular da pessoa de Jesus a fé cristã alcançou uma mudança muito profunda e conseqüente na compreensão do ser humano. Em Cristo, todo ser humano precedente foi substituído por uma forma radicalmente nova de ser pessoa. É um episódio que se dá, sobretudo, na ressurreição de Jesus $^{59}$.

\footnotetext{
${ }^{59}$ PANNENBERG, W. "Fundamentação Cristológica de uma antropologia cristã". Concilium, ano: $1973, \mathrm{n}^{\circ} \mathrm{X}, \mathrm{p} .734$.
} 
O sentido da existência humana, como também, o sentido último da história individual tornou-se realidade cumprida em Jesus Cristo ${ }^{60}$. É importante recordar a comparação feita por Paulo do primeiro homem, criado da terra corruptível e, o segundo, chamado por ele de homem celestial, por isso, imortal, tal como se manifestou na ressurreição de $\mathrm{Cristo}^{61}$. O texto Paulino procura mostrar a convergência entre o primeiro e o segundo homem. Convergência que acontece na história de Jesus. Pode-se dizer que há uma correlação entre pecado e reconciliação, acontecida em Jesus Cristo, pois, do contrário, a pessoa humana permaneceria na escravidão do pecado ${ }^{62}$.

Para Pannenberg, não é estranho afirmar que no plano da salvação cada pessoa se faz inserida na história de Jesus, uma vez que a sua história define a história de cada pessoa, e a mesma é capacitada para a superação da contingência, capacitando-a, assim, para que seja elevada até Deus. A história, bem percebe o teólogo luterano, é a história dos feitos de Deus ${ }^{63}$. O feito que marca por definitivo a história da humanidade é o envio do Filho ao mundo. Em Jesus, verifica-se a unidade da história, todo ser humano participa, de forma proléptica, no chamado fim da historia. O fim da história é compreendido por Pannenberg como um momento escatológico da revelação divina. O fim, aqui apresentado, representa a plenitude da jornada salvífica, oferecida por Deus ao ser humano. Com o acontecimento pascal, já acontece na história humana a totalidade de sua humanização e a plenificação do seu sentido. É na pessoa de Jesus ressuscitado que a história humana se liga de forma definitiva com o Deus Pai criador. No momento em que o ser humano participa da ressurreição de Jesus, participa igualmente da vida eterna de Deus.

O teólogo luterano deixa explícito que é na pessoa de Jesus Cristo que o ser humano encontra por definitivo a sua salvação, realizando de forma plena a sua existência. A história de Jesus, como história de salvação, coloca-se em convergência com a história da pessoa humana. A esperança humana, confirmada na ressurreição de Jesus, já possibilita no presente à pessoa vivenciar, de forma proléptica ${ }^{64}$, o fim que a espera. No acontecimento Jesus Cristo, a

${ }^{60}$ GÓZDZ, KRZYSTOF. Jesus Christus als Sinn der Geschichte bei Wolfhart Pannenberg. Regensburg: Fridrich Pustet, 1988, p. 134.

${ }^{61}$ PANNENBERG, W. Anthropologie in theologischer Perspektive. p.485.

${ }^{62}$ PANNENBERG, W. Die Bestimmung des Menschen: Menschsein, Erwählung und Geschichte. Göttingen: Vandenhoeck \& Ruprecht, 1978, p. 7.

${ }^{63}$ PANNENBERG, W. Grundfragen systematischer Theologie Band 2. 1980, p.115.

${ }^{64}$ A palavra proléptico em Pannenberg não deixa de proporcionar alguma dificuldade, pois ela parece sintetizar em um conceito único o "já" e o "ainda não". Não há dúvida que tal conceito 
pessoa já vive o começo do fim universal da história ${ }^{65}$. A ressurreição de Jesus é o episódio que o coloca na condição de transcendência. A história, como limite e contingência, vê-se superada n'Ele. Do mesmo modo, o ser humano é conduzido ao caminho da transcendência divina.

A cristologia apresentada nesse artigo mostra que na pessoa e história de Jesus Cristo, a definição de pessoa humana chega a sua plenificação. Em toda pessoa, compreende-se a totalidade da vida humana na unidade consigo mesma, com o mundo, com os outros e com Deus ${ }^{66}$. Pelo viés da história de Jesus Cristo, alarga-se a compreensão do ser pessoa, oferecendo ao conceito de existência humana e à sua historia algo a mais. Agora, o desejo de realização plena do ser humano já se faz realidade pela história de Jesus. $\mathrm{O}$ indivíduo não está entregue à própria sorte, como também não está a sua história, pois ambos agora seguem um rumo certo e definitivo. Uma luz já brilhou no horizonte da vida humana, parafraseando aqui o texto bíblico que diz: "o povo que andava nas trevas viu uma grande luz" (Is 9,1). Ainda acrescenta-se a essa passagem outra, não menos sábia e reveladora: "o sol nascente nos veio visitar" (Lc 1,78).

Pannenberg entende que somente quando Jesus é visto como aquele que vai iluminar o percurso da vida e da história humana, então sim, há como compreendê-lo como o sentido final da historia universal. Para ele, o sentido final da história não se encontra no próprio ser humano, pois esse, como ser finito, não tem condições de alcançar tal grandeza. É a revelação de Deus, na pessoa de Jesus Cristo, que ilumina a história humana, elevando a mesma à plenitude de sentido ${ }^{67}$. Na ressurreição de Jesus, foi revelada a totalidade de

representa o mesmo dilema do ser humano quando relaciona presente e futuro. O ser humano não consegue fazer uma síntese perfeita entre passado, presente e futuro, pois isso ultrapassaria a sua condição de criatura.

${ }^{65}$ GÓZDZ, KRZYSTOF. Jesus Christus als Sinn der Geschichte bei Wolfhart Pannenberg. Regensburg: Fridrich Pustet, 1988, p. 137.

${ }^{66}$ PANNENBERG, W. Grundzüge der Christologie . p.197. Aqui, mostra-se comprovado o fundamento cristológico de W. Pannenberg. A sua cristologia traz algo muito novo que é a fundamentação antropológica. Jesus Cristo e sua vida devem ser compreendidos a partir da história, ou melhor, situados na história humana.

${ }^{67}$ Afirma Pannenberg: "o que em primeiro momento como sem significado aparece, recoloca-se talvez mais tarde com importância fundamental - retorna. O significado definitivo do acontecimento de nossa vida, nós somente o conhecemos ao final da vida. Podemos calcular tal significado apenas na hora da morte. Em virtude da historicidade, a experiência de sentido, mesmo porque a totalidade da história da vida é um processo, ela aparece no futuro e embora particularmente no último futuro, uma decisiva função para a pergunta sobre o sentido de nossas vidas na totalidade e depois do definitivo significado dos acontecimentos individuais". 
sentido ao ser humano, mas é somente no futuro escatológico que o mesmo alcançará tal totalidade. No processar da história, seria contraditório querer alcançar a totalidade da verdade, daí o tamanho valor atribuído ao desfecho final da história, em que haverá a unificação plena de todas as suas partes, ou seja, a história universal. É nesse contexto que se compreende o título dado a Jesus Cristo de rei do universo, pois ele participa do reinado do Pai, como Filho que cumpriu sua missão de elevar à perfeição o gênero humano.

Pela experiência da fé vivenciada na comunidade a pessoa vai a caminho de sua perfeição. A consciência religiosa e a busca de sentido para a própria existência acontecem na vontade de comunhão do indivíduo para com Deus em Jesus Cristo ressuscitado. A comunhão da pessoa com Jesus insere a história humana no caminho da perfeição e a capacita para participar da vida de Deus. Não somente o individuo se constrói no caminho da salvação e da experiência do amor de Deus, mas também toda comunidade ${ }^{68}$. Toda comunidade que celebra e vive a fé vai ao encontro de Jesus como a fonte da vida e do amor. Assim, Jesus não dá sentido somente para a vida da pessoa individual, mas para a história de toda sociedade. Na comunidade, as pessoas testemunham a experiência histórica do sentido verdadeiro da vida em Jesus Cristo, isso é possível, através da vivência do amor de Deus que se concretiza no amor ao próximo. A comunidade eclesial é o instrumento que antecipa a comunidade escatológica, pois através dos sacramentos e do anuncio do reino a realidade escatológica já se faz presente na vida dos crentes. Na comunidade, as pessoas participam da unidade com o Cristo pela unidade com os irmãos na fé. A eucaristia é o acontecimento em que o fiel assume a mensagem de Jesus como palavra de Deus presente na vida da igreja.

Por fim, a noção panenberguiana de história da salvação é uma noção trinitária. A salvação, trazida ao ser humano por Jesus Cristo, acontece na unidade do Pai e do Espírito Santo. É o Espírito Santo quem capacita a pessoa para compreender a revelação de Deus feita em Jesus Cristo. O Espírito orienta a história humana para que a humanidade possa compreender e aceitar

Cf. PANNENBERG, W. Grundfragen systematischer Theologie Band 2. 1980, p. 73. Tal sentido que será revelado ao ser humano somente no futuro, como totalidade, já se faz claro na vida e na história de Jesus Cristo.

${ }^{68}$ É pertinente mencionar o valor da Sagrada Tradição para a vivência da fé em comunidade. Sobre tudo na teologia católica, a Tradição representa um tesouro precioso chegado até nós graças aos apóstolos, mártires, santos e doutores que nos antecederam na história cristã. Pannenberg atribui profundo valor à tradição e recorre constantemente a ela para elaborar a sua teologia. 
o mistério salvífico acontecido em Jesus Cristo. É o Espírito quem sustenta a vida da comunidade de fé. Ele como origem da vida, habita no crente e permanece nele. Por sua força se realiza a unidade da comunidade humana com Deus Pai.

A essência da atuação do Espírito na vida da comunidade transcende e supera o isolamento das pessoas. Mostra Pannenberg que o espírito de um povo, de uma época ou de uma cultura, em cada caso, são manifestações particulares do Espírito de Deus na história ${ }^{69}$. O Espírito já é a presença do futuro escatológico na vida da Igreja que crê e na vida da comunidade eucarística. Ele faz com que a Igreja seja qualificada, mediante a sua ação, para a participação antecipada no destino definitivo do ser humano. Ele é a dádiva oferecida à humanidade, da vida nova e imperecível, que já emergiu no Cristo ressuscitado. É o Espírito quem unifica com o Pai e o Filho toda história humana. Ele é dom que prepara o coração humano para receber a salvação oferecida por Jesus Cristo. Ele nos liberta de todos os sofrimentos e nos capacita para a verdadeira liberdade de filhos de Deus.

\subsection{Libertados plenamente no Deus de Jesus Cristo}

Para Pannenberg, a liberdade, como realização cristã do ser humano, tem seu verdadeiro sentido em Jesus Cristo. A nossa preocupação neste momento é fazer uma breve exposição da ideia de liberdade plena alcançada na pessoa de Jesus Cristo e, logo em seguida, ainda na mesma temática, colocar alguns fundamentos bíblicos do tema da liberdade cristã.

Nos longos debates que Pannenberg realiza com vários autores sobre o tema liberdade, fica evidente em seu posicionamento que o sujeito humano só realiza o seu destino de liberdade quando busca fundamentá-lo em Deus. Ao afirmar que o destino do ser humano é o caminho da felicidade e do bem, não se deve esquecer que a pessoa, no exercício de sua liberdade, está sujeita a se contradizer na sua escolha e pode escolher equivocadamente, isso devido aos enganos e equívocos que constituem as inconsistências humanas. $\mathrm{O}$ ser humano, no exercício de sua liberdade de escolha, não tem ainda a plena clareza do que deseja e do que busca como existência. Com as dificuldades diante do uso de sua liberdade ele chega a perguntar se o destino que a ele se apresenta é a servidão e não a verdadeira liberdade. No entanto a resposta é a

${ }^{69}$ PANNENBERG, W. Anthropologie in theologischer Perspektive. p.515. 
pessoa buscar novo fundamento para a própria identidade e, no duro caminho da vida, construir a sua existência e as suas escolhas, fundamentando-as nos valores mais profundos da mesma. O que fica claro para Pannenberg é que o ser humano usará corretamente sua liberdade no momento em que ele se colocar no caminho que leva a Deus. A liberdade humana não se realiza por completo como iniciativa somente do ser humano como ser finito, mas ela também é dom e graça da parte de Deus ${ }^{70}$.

A solução da dificuldade vivida pelo ser humano na tensão existencial finito e infinito é efetuada na experiência da fé. A fé não aparece como possibilidade aberta para a pessoa, mesmo diante de sua liberdade, entretanto, é uma possibilidade que se abre, da parte de Deus, ao ser humano. Pannenberg elabora sua reflexão sobre a natureza humana e mostra que existe uma essência boa nele e que é natural. Tal essência, não impede a pessoa de experimentar, no exercício da vontade livre, o dilema constante entre centralidade e excentricidade. Quando a pessoa se abre, lançando-se para fora de si, ela verifica que há uma verdadeira desproporção vital na sua existência: um ser que é finito, mas que se vê voltado para um destino infinito ${ }^{71}$. É o momento em que a pessoa inicia, pela confiança, uma experiência de algo que é maior e que vai além de sua finitude. O ser humano livremente se abre diante do mistério e se descobre religioso.

O tema da liberdade é ainda um tema que proporciona dificuldades para chegar a um consenso formal sobre ele, mas para a teologia já se confirma a importância da liberdade ao se tratar do ser humano e da sua relação com Deus. Pannenberg mostra em sua obra que, desde os padres antignósticos, há uma preocupação em unir a noção de liberdade e de responsabilidade, pois do contrário, ficaria difícil de dar ao ser humano ou elogios ou castigos ${ }^{72}$.

A liberdade total do ser humano somente pode ser experimentada na sua abertura para Deus. O autor alemão insiste que é se abrindo a Jesus Cristo, numa resposta positiva à Graça, que a pessoa é verdadeiramente livre. É pelo sim dado a Deus, na fé em Jesus que a pessoa encontra sua salvação como libertação plena e total. Em tal compreensão, a liberdade não é uma conquista

\footnotetext{
${ }^{70}$ Pannenberg na sua obra a ideia de Deus e a liberdade humana mostra que liberdade e fé são compatíveis, elas se complementam uma vez que Deus é a fonte da verdadeira liberdade. Para uma boa noção do que diz o teólogo luterano nessa temática, conferir a recensão de Robert T. Osborn. Cf. OSBORN, T. Robert. Recensão da obra The Idea of God and Human Freedom. By Wolfhart Pannenberg. The Westminster Press: Philadelphia, 1973. Theology Today, 31, 1974, p. 84-88.

${ }^{71}$ PANNENBERG, W. Anthropologie in theologischer Perspektive p. 101.

${ }^{72}$ Cf. Ibid., p. 108.
} 
pessoal, ela sim é dom e Graça oferecidos aos seres humanos. É Jesus Cristo que se oferece ao ser humano como liberdade total, sendo somente nele que se dá a Graça da verdadeira liberdade. A compreensão de Jesus Cristo como aquele que vem libertar o ser humano plenamente é muito presente nos textos bíblicos, sobretudo nos textos paulinos, em que tal abordagem se faz bastante acentuada. Nesse sentido torna-se importante apresentar alguns traços que caracterizam o tema liberdade no contexto bíblico-cristão. Não deixa de ser uma exposição que complementa o conceito de liberdade na perspectiva teológico-cristã.

\subsection{A noção bíblico-cristã do tema liberdade}

Ao situar a liberdade humana na perspectiva da dimensão bíblicocristã, o teólogo luterano faz entender que liberdade e essência humana se mostram idênticas. $\mathrm{O}$ autotranscender do ser humano no uso da sua liberdade, na verdade, não é superação livre de todos os condicionamentos, é Graça de Deus. Principalmente no Segundo Testamento, a liberdade não é vista como algo próprio do ser humano, mas como efeito da presença salvadora de Cristo e de seu Espírito (Jo 8,36; 2Cor 3,17)) $)^{73}$.

Se, na sua antropologia, o autor alemão não explicita tão amplamente o tema da obediência em relação à liberdade, isso se torna mais visível no seu tratado cristológico, em que Jesus, como novo Adão, liberta o velho Adão exatamente na obediência ao plano do Pai, assumindo assim, a sua missão de anunciar o reino de Deus no mundo. Por esse ângulo de compreensão, a liberdade assume um caráter novo e passa a ser compreendida pelo cristão, também como serviço. Sendo assim, a liberdade não perde a sua fundamentação ontológica e teorética com base na razão e na consciência, porém ela adquire uma dimensão também de abertura e compromisso. Aceitando a mensagem de Cristo e seu projeto, o ser humano se torna verdadeiramente livre. Pannenberg usa o texto paulino para afirmar que a pessoa humana é libertada "em virtude da libertação realizada em Jesus Cristo" (Rm 3, 24). Assim, ser libertado na liberdade oferecida por Jesus Cristo é, pois, atingir a plenitude da liberdade humana. Aos Gálatas, Paulo lembra que "na plenitude dos tempos Deus enviou o seu Filho, nascido de mulher e sujeito à lei, para pagar a alforria daqueles que estão sujeitos à lei, para que nos seja dado ser filhos adotivos" (Gl 4,4) e, mais adiante o mesmo apóstolo diz: "É para sermos verdadeiramente livres que Cristo nos libertou" (G1 5,1). A liber-

${ }^{73}$ Cf. Ibid., p. 108. 
tação que Jesus oferece ao ser humano é fundada na obediência ao Pai e na sua unidade com Deus para a realização do projeto de implantação do Reino. Dessa forma, a liberdade de Jesus não se dá numa reivindicação de um "livre arbítrio" para se decidir diante de Deus Pai, mas consiste na sua unidade com Deus ${ }^{74}$.

Antes da plenitude dos tempos e da chegada definitiva do Reino, o ser humano ainda vive sua liberdade limitada pela lei e pelas fraquezas; não se entregando a essa realidade, a da liberdade contingente desse mundo, a pessoa carrega consigo a esperança da liberdade plena sustentada na fé cristã e no horizonte escatológico do seu desejo de infinito. A libertação plena é uma esperança futura, porém já se faz presente na vida do cristão, conseqüentemente libertado pela experiência da fé ${ }^{75}$.

A liberdade, no sentido cristão, é a comunhão com Jesus e a participação na sua filiação junto do Pai. Ser co-participante na filiação é ao mesmo tempo ter responsabilidade na instauração do reino de Deus, que é a missão de Jesus. A liberdade verdadeira permite ao ser humano, na crise diante de si e diante de Deus, superar essa crise e se deixar reconciliar com Deus. Mesmo com o peso da angústia existencial, que marca a sua trajetória, o ser humano que escolhe a resposta cristã para o uso de sua liberdade, vive sua vocação criatural e experimenta a sua verdadeira liberdade de filho de Deus, assumindo uma identidade autêntica como indivíduo. Compreendida assim, a liberdade não é somente a liberdade da formulação conceitual filosófica como determinação da vontade, mas é também fruto da Graça, é dom do Espírito, que não liberta os seres humanos unicamente da sua fixação no próprio ego, nem eleva, sobretudo, além de sua finitude, mas lhes tornam permanentemente livres e os fazem participantes da filiação de Jesus Cristo $(\operatorname{Rm} 8,13 \mathrm{~s})^{76}$.

A liberdade cristã é dom oferecido por Deus ao ser humano. É pela abertura, como escuta ao convite feito por Deus à pessoa situada na história, que ela supera a situação de pecado e de fechamento, projetando-se para além de seu horizonte de fechamento numa atitude de excentricidade. Nesse processo, a liberdade se faz liberta do egoísmo e da servidão, colocando o ser humano diante da missão de ser sinal do amor de Deus entre os seres humanos, tornando-se também abertura para a vivência do amor fraterno ${ }^{77}$.

\footnotetext{
${ }^{74}$ PANNENBERG, W. Grundzüge der Christologie, Gütersloh: Gütersloher Verlaghaus Gerd Mohn, 1964, p. 363s.

${ }^{75}$ PANNENBERG, W. Systematische Theologie. Band 3, p. 104s.

${ }^{76}$ Cf. Ibid., p.135s.

${ }^{77}$ Sobre o tema do amor fraterno cabe indicar a obra de Mário de França Miranda. A Salvação de Jesus Cristo . A doutrina da Graça. São Paulo: Loyola, 2004, p.125-149.
} 
Por fim, pode-se dizer que a liberdade humana é uma grande conquista no decorrer da história da cultura. Não seria possível falar do ser humano retirando dele o princípio de liberdade; logo, a mesma se faz intrínseca a ele. Se por um lado, a liberdade é um princípio universal, formulado e fundamentado na razão formal, tornando-se assim um princípio necessário e, para muitos, absoluto, por outro lado, ela ainda é uma realidade incompleta, e a cada dia o ser humano deseja mais e mais liberdade. Desse modo, no processo das reflexões sobre o tema liberdade cristã, há de se pontuar que a sua plenitude conceitual ainda não se concilia com sua dimensão empírica. O descompasso entre conceito e experiência tem a sua solução em Jesus Cristo.

Pannenberg, marcado pela modernidade, pontua como é imprescindível a liberdade humana. Para ele a liberdade se torna plena e absoluta somente em Deus, através de Jesus Cristo. Assim, o cristão que responde com sua fé ao amor de Deus é uma pessoa verdadeiramente liberta. Para complementar o sentido dessa afirmação antecedente, é necessário abordar a pessoa de Jesus Cristo como aquele que revela o Deus libertador, indicando-nos o caminho da plenitude humana. Ele é quem nos liberta de forma definitiva reconciliando toda a humanidade com o Pai.

\subsection{Com a ressurreição Jesus Cristo salva e reconcilia o gênero humano}

Antes de terminarmos o artigo, faz-se necessário retomar o tema da salvação, procurando de forma mais restrita verificar como Pannenberg apresenta Jesus Cristo como salvador da humanidade. A profissão de fé que designa Jesus como Deus e salvador de toda humanidade, forma a confissão básica do concílio mundial das Igrejas. Na pessoa de Jesus e na sua ressurreição, concretiza-se a esperança de salvação para a humanidade. Na novidade da pessoa de Jesus Cristo, a salvação vai além dos limites da esfera da tradição judaica. Essa afirmação não deixa de pressupor que a expectativa judaica de ressurreição dos mortos possa ser afirmada como plausibilidade suficiente e de valor universal na pessoa de Jesus ${ }^{78}$. Pannenberg chega à conclusão de que

${ }^{78}$ PANNENBERG, W. Systematische Theologie. Band 2 , p. 393. Também o autor americano Stanley J. Grenz na obra Reason for Hope, recorda que a mensagem de Jesus aponta para uma futura confirmação conforme sugere Pannenberg. "A Igreja primitiva encontra sua confirmação na ressurreição de Jesus de entre os mortos. Como mostra o teólogo alemão, esse evento funda o ponto inicial para a afirmação cristológica da unidade de Jesus com Deus". Cf. GRENZ, J. Stanley. Reason for Hope. The Systematic Theology of Wolfhart Pannenberg. Michigan: William B. Eerdmans publishing Company, Second edition, 2005, p.157. 
Jesus se tornou o Salvador dos povos: primeiro em decorrência da rejeição de sua missão por seu próprio povo e, depois por meio de sua paixão e cruz. Como o Crucificado e o Ressurreto, ele é o novo homem, escatologicamente definitivo ${ }^{79}$. Em Cristo Jesus veio a salvação aos pagãos, como escreve Paulo em (Rm 11,11). A rejeição de Jesus, aos olhos de Paulo, foi um mal que se transformou num bem.

O acontecimento da ressurreição confirma a missão terrena de Jesus e revela o desfecho positivo de sua missão no mundo. Jesus é exaltado pelo Pai, tornando-se assim, participante do reinado de Deus sobre o mundo. É nesse contexto, que se compreendem as figuras da expectativa escatológica: como elevação à dignidade de Messias ou de Filho do Homem. O evento pascal deve ser entendido como a confirmação da mensagem de Jesus e o cumprimento da sua pregação acerca da irrupção iminente do futuro reino de Deus. A salvação derradeira, para todo ser humano, já se tornou realidade em Jesus no seu ressuscitamento dentre os mortos $^{80}$.

Para o teólogo luterano, parece impossível separar a soteriologia da cristologia, pois é aquela que faz se perguntar sobre a história e a pessoa de Jesus $^{81}$. Jesus é o Cristo, único salvador de toda humanidade. Essa afirmação encontra sustentabilidade na história de Jesus, através do seu compromisso de anunciar o reino de Deus, na sua obediência ao Pai e na sua forma de atuar junto das pessoas. A sua vivência, junto do ser humano, já revelava a salvação e o amor de Deus a todos, mas, sobretudo aos pobres. A afirmação do amor salvador de Deus, como ato de fé dos primeiros cristãos solidificar-se-á no evento da ressurreição de Jesus. A ressurreição é o sim do Pai a Jesus e a toda humanidade. Ela confirmou aos primeiros seguidores de Jesus que o projeto do reino não havia fracassado.

O envio do Filho ao mundo visa à reconciliação desse com seu criador, a saber, das pessoas e, por meio delas, toda a criação se reconcilia com Deus. Nele, cumpriu-se a esperança da salvação de Israel, aprofundando-a e libertando-a de suas limitações. Jesus como o Messias é simultaneamente o novo homem escatológico. Ele, como enviado do Pai, para realizar uma missão, cria

\footnotetext{
${ }^{79}$ Ibid., p. 352. A singularidade da salvação trazida ao ser humano por Jesus Cristo constitui também a singularidade do governo de Javé. Tal singularidade é desenvolvida no antigo Israel e se vê expressa no primeiro mandamento. Como fala Zacarias: "Javé se tornará rei sobre toda a terra; naquele dia, Javé será único e seu nome será único” (Zc 14,9).

${ }^{80}$ Ibid., p. 409.

${ }^{81}$ PANNENBERG, W. . Grundzüge der Christologie. p. 41
} 
espaço e condições para que o reino de Deus aconteça entre todas as pessoas. A sua ação está voltada para a renovação da comunhão entre as pessoas e das pessoas para com Deus. A salvação, apresentada por ele, consiste na comunhão com Deus e na fundamentação da vida nessa comunhão; abrangendo a renovação da comunhão dos seres humanos entre $\mathrm{si}^{82}$. A certeza de estar em comunhão com Deus, através de Jesus Cristo, sustentou toda mensagem apostólica; esse estado de coisas já garante a participação no Reino de Deus vindouro. Pode-se dizer que a salvação está ligada ao relacionamento do ser humano com o futuro de Deus.

É Paulo quem vai mostrar que o futuro escatológico é marcado também por um juízo (Rm 5,9; $1 \mathrm{Ts} 1.10 ; 5.9 \mathrm{~s}$ ). Ele fala do juízo, mesmo considerando que a salvação já é uma realidade certa para todo aquele que crer que Jesus é o Senhor e salvador. É em um contexto de esperança futura que a teologia paulina possibilita a relação entre o presente e o tempo vindouro do Reino de Deus, como continha a mensagem ensinada por Jesus. A garantia da salvação humana já é realidade ao crente, acessível já agora; daí que se pode compreender o termo soteria, que em Paulo, toma também o sentido de justificação $(\operatorname{Rm} 5,10 ; 5.18)^{83}$. A justificação se dá na morte de cruz e ressurreição de Jesus. Na paixão de Jesus, o ser humano já foi absolvido e reconciliado com Deus. Nos textos de (1Cor 15.2; 2Cor 6.2) Paulo confirma que a salvação já é dada no poder do evangelho, em Efésios ele volta a reforçar tal afirmação (Ef 2.5 e 8), e na carta a Tito mostra que os crentes já receberam a salvação por meio do Batismo (Tt 3.4s). As variações na forma de compreender o conceito de salvação não são tão significativas, pois o mais relevante que se quer retratar tanto em Paulo quanto nos evangelhos é o sentido salvífico da cruz e ressurreição de Jesus. O que está por detrás de tal afirmação é a ideia da pessoa de Jesus como reconciliador e salvador de toda humanidade.

Ainda no tema da reconciliação, como afirmou Paulo, Jesus representa o novo Adão. Se o primeiro foi quem rompeu a harmonia entre criatura $\mathrm{e}$ criador, ao segundo, Jesus Cristo, coube reatar o elo dessa harmonia. Jesus reconcilia o mundo com o Criador. Como já pensava Irineu, a reconciliação salvífica se dá pela obediência do Filho à vontade do Pai ${ }^{84}$. Na sua obediência, ele sela junto do Pai uma nova aliança, garantindo novamente um espaço ao

\footnotetext{
${ }^{82}$ PANNENBERG, W. Systematische Theologie. Band 2. p. 442.

${ }^{83}$ Ibid., p. 443. Justificação, resgate e reconciliação formam um conjunto indissolúvel em Paulo, de modo que as diferenças se apagam ocasionalmente.

${ }^{84}$ Ibid., p. 448 et. seq.
} 
ser humano ao lado de Deus. A sua morte não foi pelos próprios pecados, mas pelos dos outros; as demais pessoas não precisam mais se entender como excluídas da comunhão com Deus. Na doação de Jesus ao Pai, substituindo o ser humano na reparação dos pecados, ele abre um horizonte de esperança renovada. Esperança definitiva, eterna, selada na cruz com a própria morte. $\mathrm{O}$ Filho se doa a toda humanidade.

Finalmente, a consumação da reconciliação se dá com a presença do Espírito Santo. É ele quem capacita o ser humano para receber a salvação trazida por Jesus Cristo. O Espírito, como fonte de vida, gera a comunhão dos seres humanos com seu Criador, comunhão rompida pelo poder do pecado $^{85}$.Somente no Espírito a pessoa humana tem condições de participar da comunhão de Jesus Cristo com o Pai (G1 3,26s; Rm 8,14s). Em 2 Cor 3,17, Paulo chega a identificar o Espírito com o Senhor. Assim, aos crentes cabe a habitação do Espírito, é Ele quem sustenta a vida do crente e o anúncio da mensagem do reino ( $\mathrm{Rm} 8,9)$. No Espírito, o ser humano recebe a reconciliação que Deus realizou na morte de seu Filho, nele a humanidade é integrada como membro do corpo de Cristo (1Cor 6,17). Pelo Espírito, Cristo continua presente no mundo, salvando e libertando até a chegada da salvação definitiva.

\section{Conclusão}

A síntese cristológica de Pannenberg esforça-se em manifestar o mistério da revelação de Deus no contexto da história de Jesus. Ela, porém, não desconsidera a sua dimensão vertical como cristologia do alto. Não há como negar o esforço do autor alemão em buscar harmonizar as duas cristologias. Mesmo atribuindo grande valor à cristologia de baixo ele se vê obrigado a recorrer a cristologia de cima ${ }^{86}$.

A afirmação de Jesus como salvador da humanidade ainda é um problema debatido no universo das religiões. John Hick é um teólogo que não aceita a posição de Pannenberg quando este afirma a universalidade salvífica do cristianismo revelada em Jesus Cristo. A compreensão cristológica de Hick não tem dificuldade para relativizar o papel de Jesus Cristo como salvador, o que para o teólogo luterano se mostra inaceitável. Hick chega a dizer que não é indispen-

\footnotetext{
${ }^{85}$ Ibid., p. 496. Pannenberg, assim como o fez K. Rahner, reconhece a unidade trinitária no acontecer revelatório da história da salvação.

${ }^{86}$ O’ DONNELL, John. “Pannenberg’s doctrine of God”. Gregorianum, Roma, v. 72, n. 1, p. 553, 1991.
} 
sável o sentido histórico da salvação que tem Jesus como mediador ${ }^{87}$. Para nós a defesa de Pannenberg nesse caso se faz necessária, pois a sua posição garante a validade universal do cristianismo e da salvação de Jesus Cristo.

Pannenberg deixa claro que a confissão de fé em Jesus como salvador não é fruto somente de uma experiência do presente da comunidade, ela precisa antes perguntar quem foi Jesus e a pergunta apresentada nos obriga a deparar com o todo de sua história. A ressurreição é o fato máximo da história de Jesus, ela representa o sim do Pai a Jesus e também a toda humanidade. Ela possui um valor retroativo, ou seja, representa o ponto de partida ${ }^{88}$, não somente no reconhecimento da união de Jesus com o Pai, mas pela força que ela proporciona às comunidades cristãs.

A noção da expectativa apocalíptica é necessariamente vital como pano de fundo para compreender a ressurreição de Jesus Cristo. Sem tal horizonte não seria possível de entender como o homem Jesus é sugerido ser a revelação definitiva de Deus ${ }^{89}$. A cristologia de Pannenberg deixa claro que tal compreensão já é um dado revelado, que se faz presente de forma proléptica, mas ele se tornará realidade plena somente no fim da história. É proléptico porque a ressurreição já é realidade acontecida em Jesus, mas para nós ela ainda faz parte de uma esperança futura. É um futuro que representa exatamente a transcendência da história, o dilema que o ser humano vive entre o "já" e o "ainda não". É nesse sentido que a totalidade da história que converge na pessoa de Jesus Cristo é, sem dúvida, ponto ápice da teologia de Pannenberg.

\section{Referências Bibliográficas}

\section{Obras de Wolfhart Pannenberg}

PANNENBERG, W. Anthropologie in theologischer Perspektive. Göttingen: Vandenhoeck \& Ruprecht, 1983.

Die Bestimmung des Menschen: Menschsein, Erwählung und Geschichte. Göttingen: Vandenhoeck \& Ruprecht, 1978.

\footnotetext{
${ }^{87}$ HICK, John. "A Note on Pannenberg's Eschatology". The Harvard Theological Review, Vol. 77,3/4, (Jul-Oct), 1984, p. 421-423.

${ }^{88}$ O'COLLINS, G. G. “The Christology of Wolfhart Pannenberg”. Religious Studies, Vol. 3, n.1, 1967, p 373.

${ }^{89}$ PANNENBERG, W. Grundzüge der Christologie. p. 79.
} 
"Fundamentação cristológica de uma antropologia cristã". Concilium 6 (1973).

Grundfragen systematischer Theologie, Band 2. 1980.

Grundzüge der Christologie. Gütersloh: Gütersloher Verlaghaus Gerd Mohn, 1976.

"Jesus Cristo - o critério da nossa fé no verdadeiro e único Deus".

Humanística e Teologia, Vol. 3, ano 2003, p.337-356.

Teologia e Reino de Deus. Salamanca: Sigueme, 1974.

Systematische Theologie. Band 2. Gottingen: Vandenhoeck \& Ruprecht, 1991.

Systematische Theologie. Band 3. Göttingen: Vandenhoeck \& Ruprecht, 1993.

\section{Outras obras}

A Bíblia - Tradução Ecumênica. São Paulo: Paulinas; Loyola, 1995.

BOFF, Clodovis. Recensão da obra Teologia sistematica 1, Queriniana: Brescia, 1990. REB, Petropolis, v. 52, n. 205, p. 229-230, mar. 1992.

FERNÁNDEZ, José Ramón Matto. "Il Futuro Del Hombre y el ser de Dios. La Escatología Trinitária”. Salmanticensis, Vol. LVI, fasc. 3, p. 445-494, 2009.

GÓZDZ, KRZYSTOF. Jesus Christus als Sinn der Geschichte bei Wolfhart Pannenberg. Regensburg: Fridrich Pustet, 1988.

GRENZ, J. Stanley. Reason for Hope. The Systematic Theology of Wolfhart Pannenberg. Michigan: William B. Eerdmans publishing Company, Second edition, 2005.

HICK, John. "A Note on Pannenberg's Eschatology". The Harvard Theological Review, Vol. 77,3/4, (Jul-Oct), 1984, p. 421-423.

O'COLLINS, G. G. "The Christology of Wolfhart Pannenberg”. Religious Studies, Vol. 3, n.1, 1967, p 373.

O’ DONNELL, John. Pannenberg's doctrine of God. Gregorianum, Roma, v. $72, n^{\circ} .1,1991$, p. 553. 
OSBORN, T. Robert. Recensão da obra The Idea of God and Human Freedom. By Wolfhart Pannenberg. The Westminster Press: Philadelphia, 1973. Theology Today, 31, 1974, p. 84-88.

SHULTS, Leron. The Postfoundationalist Task of Theology: Wolfhart Pannenberg and the New Theological. Grand Rapids: Eerdmans, 1999.

SCHNEIDER, Theodor (org.). Manual de Dogmática, Vol. I. Cristologia. São Paulo: Vozes, 2002, p. 219-400.

VILADESAU, Richard. Recensão da obra The Postfoundationalist Task of Theology: Wolfhart Pannenberg and the New Theological. By F. LeRon Shults. Grand Rapids: Eerdmans, 1999. Theological Studies, Washington, v. 61, n. 3, p. 594, Sep. 2000.

\section{Romildo Henriques Pinas}

Doutor em Teologia pela Pontifícia Universidade Católica do Rio, trabalha em projeto social dos salesianos de Dom Bosco em Niterói. E-mail: romildo@salesiano.br

Artigo Recebido em 14/05/2012 Artigo Aprovado em 20/08/2012 